http://dx.doi.org/10.18778/1508-1117.23.04

Matgorzata Twardzik

\title{
ODDZIALYWANIE GALERII HANDLOWYCH NA ŚRÓDMIEJSKIE ULICE HANDLOWE KATOWIC
}

\begin{abstract}
Zarys treści: Galerie handlowe stały się w Polsce nieodłącznym elementem struktury współczesnych miast dużych oraz średniej wielkości. W Katowicach funkcjonują dwa obiekty w dzielnicy śródmiejskiej i oddziałują pod wieloma względami na funkcjonowanie Katowic. Rozpatrując ich miejsce w strukturze sieci handlowo-usługowej miasta można postawić tezę, że przyczyniają się zarówno do aktywizacji gospodarczej strefy śródmiejskiej, czego dowodem mogą być licznie powstające placówki gastronomiczne, rekreacyjne, usługowe oraz handlowe, jak i drenowania funkcji handlowej z ulic śródmiejskich.
\end{abstract}

Słowa kluczowe: galerie/centra handlowe, handel wielkopowierzchniowy, miasto, dzielnica śródmiejska.

\section{Wprowadzenie}

Galerie handlowe stały się nieodzownym elementem krajobrazu współczesnych miast w Polsce. Wielkogabarytowe, wielofunkcyjne, nowoczesne obiekty stanowią coraz częściej alternatywę dla śródmiejskich dzielnic handlowych. W Katowicach, największym mieście województwa śląskiego, a zarazem stolicy Górnośląskiego Związku Metropolitalnego funkcjonują dwie duże Galerie Handlowe: Silesia City Center oraz Galeria Katowicka, a także kilka dzielnicowych centrów handlowych (Centrum Handlowe 3 Stawy, Centrum Handlowe Dąbrówka, Centrum Handlowe Auchan). W październiku 2015 roku otwarto trzecią galerię śródmiejską - Supersam. W sieci handlowej miasta dominują małe sklepy osiedlowe oraz dyskonty spożywcze (Biedronka, Lidl, Netto, Aldi) i sieci zintegrowane (Żabka, Lewiatan, Małpka, Delikatesy Centrum, Od i Do i inne). Specyfiką miejsca jest aglomeracja, na którą składa się 19 miast w bezpośrednim sąsiedztwie, tworząc obszar zamieszkały przez ponad 2,5 mln. ludzi. Niemal w każdym z miast aglomeracji są ulokowane galerie handlowe. 
Śródmieście Katowic wyposażone w funkcje handlowo-usługowe traci w ostatnich latach swoją dominującą pozycję w obsłudze mieszkańców na rzecz galerii handlowych. Ulice handlowe coraz częściej dotyka problem stabilnego najmu powierzchni, odpowiedniego asortymentu i konkurencyjnych cen towarów i usług. Niedostatek miejsc parkingowych, wysokie stawki czynszu oraz brak nowoczesnych udogodnień pozbawiają je niejednokrotnie możliwości funkcjonowania. Celem artykułu jest rozpoznanie, w jakim zakresie galerie handlowe oddziałują na śródmiejskie ulice Katowic. W szczególności badaniu poddano warunki funkcjonowania handlu w ulicach śródmiejskich oraz w Galerii Katowickiej, która jest zlokalizowana w ścisłym śródmieściu, w połączeniu z dworcem kolejowym oraz autobusowym ${ }^{1}$. W tym celu przeprowadzono w czerwcu 2014 roku badania wśród 400 mieszkańców miasta, którzy korzystają z oferty zarówno galerii, jak i śródmiejskich placówek handlowo-usługowych ${ }^{2}$. Badania przeprowadzono metodą ankiety, techniką ankiety rozdawanej, z wykorzystaniem kwestionariusza. Wyniki badań można uznać za wstęp do dalszych kompleksowych analiz statystyczno-przestrzennych funkcjonowania różnych formatów handlu w strukturze sieci detalicznej Katowic.

\section{Oddziaływanie centrów handlowych na strukturę funkcjonalno-przestrzenną miasta - przegląd literatury}

Współczesne teorie rozwoju lokalnego i regionalnego traktują handel wielkopowierzchniowy (m.in. centra handlowe) jako jeden z czynników otoczenia i nie doceniają jego bezpośredniego wpływu na procesy rozwojowe. Problematyka oddziaływania centrów handlowych na strukturę funkcjonalną miasta została już podjęta w wielu opracowaniach europejskich i amerykańskich, a dotyczyła głównie wyboru lokalizacji handlu, przemian jakościowych dokonujących się w miejskiej sieci usługowej oraz projektowania centrów handlowych. Do najważniejszych opracowań przekrojowych traktujących ogólnie o problematyce obiektów handlowych należy zaliczyć m.in. prace zbiorowe: Shopping. Harvard Project on the City pod redakcją R. Koolhaasa, S. Boeriego, S. Kwintera, N. Tazi, H. Urlicha Obrista. Opracowania te wzbogaca niemiecka publikacja Angriff auf die City pod redakcją W. Brunego, R. Junkera, H. Pump-Uhlmanna, traktująca w sposób krytyczny o problemach lokowania centrów handlowych na terenie Niemiec. Zagadnienia związane z projektowaniem centrów handlowych oraz ich rozwojem przekrojowo opisał P. Coleman w książce Shopping Environments: Evolution, Planning and Design. W ujęciu historycznym w interesujący sposób rozwój myśli związanej z lokowaniem handlu przedstawia A. Wall w książce Victor

\footnotetext{
${ }^{1}$ Badania dotyczyły tylko galerii handlowej, nie badano funkcji komunikacyjnej.

${ }^{2}$ Opis badanej próby respondentów i zakres badań opisano w części empirycznej opracowania.
} 
Gruen: From Urban Shop to New City. Wytyczne dotyczące projektowania centrów handlowych w Stanach Zjednoczonych zawarto w zbiorowej publikacji wydanej przez Urban Land Institute pt. Shopping Center Development Handbook. Podręcznikiem ocen oddziaływania obiektów handlowych na tradycyjny handel jest książka J. Englanda Retail Impact Assessment. Informacje dotyczące prawodawstwa krajów europejskich zawarto m.in. w dziele zbiorowym pod redakcją S. Howe'a pod tytułem Retailing in the European Union. Structures, Competition and Performace oraz w artykule C. Guy'a Controlling New Retail Spaces: The Impress of Planning Policies in Western Europe. Wśród polskich badaczy nowoczesnych formatów handlu wymienić należy: W. Budnera, J. Mikołajczyka, A. Szromnika, J. Dzieciuchowicza, A. Rochmińską czy też E. Maleszyka, W. Wilka, B. Pokorską. Pojedyncze projekty prezentowane są także na łamach czasopism branżowych, takich jak: „Architektura-Murator”, „Architektura \& Biznes”, czy „Urbanista”. W Europie wykonywane są badania dotyczące przemian jakościowych dokonujących się w miejskiej sieci usługowej w powiązaniu z realizacją obiektów handlowych. Jako jednego z głównych badaczy tematu należy wymienić C. Guy'a (z jego licznymi publikacjami, w tym: The Retail Development Process: Location, Property and Planning oraz Retail Location Analysis). Ponadto znane są badania, jakie wykonał R. Monheim w niemieckim Bayreuth (opublikowane m.in. w dziele zbiorowym Angriff auf die City). Podobne badania przeprowadził M. Franke w Bautzen w Niemczech i opublikował w swojej książce Lokaler Einzelhandel und Shopping-Center: Eine Betrachtung zu den Auswirkungen eines integrierten Shopping-Centers. Istnieją również inne publikacje dotyczące poszczególnych krajów Europy środkowo-wschodniej, m.in. E. Lukić, I. Jakovčić, J. Maryáš, J. Kunc, Z. Szczyrba.

\section{Galerie handlowe w Katowicach}

Największe powierzchniowo nowoczesne formaty handlu to centra handlowe 3 . Wielkość i cechy centrum są determinowane charakterystyką rynku oraz strefą zasięgu, jaką obsługuje centrum (Matysiak 2009). Istotnymi wymogami dla galerii handlowych ${ }^{4}$ są: wyłączenie ruchu kołowego wewnątrz obiektu, istnienie parkingu, łatwa dostępność komunikacyjna, klimat handlowy podkreślany elementami i urządzeniami rekreacyjnymi (Strużycki 2000). Dominującą funkcją ekonomiczną każdego centrum handlowego pozostaje handel detaliczny. Struktura działalności handlowej jest kształtowana przez oczekiwany popyt, przewidywane

${ }^{3}$ Międzynarodowa Rada Centrów Handlowych definiuje centrum handlowe jako zespół detalicznych placówek handlowych, usługowych oraz innych, planowany, budowany i zarządzany jako odrębna całość wraz z przyległym parkingiem.

${ }^{4}$ Pojęcia centrum handlowe, galeria handlowa oraz ośrodek handlowy będą używane w tekście zamiennie i traktowane jako tożsame. 
obroty, rentowność, warunki działania sklepów, charakter sprzedawanych towarów, oczekiwaną marżę handlową oraz bezpośrednie koszty obrotu określonymi towarami (Dzieciuchowicz 2012). Oprócz funkcji handlowej centra mogą pełnić funkcje: usługowe (placówki gastronomiczne, punkty usługowe), rozrywkowe, rekreacyjne, kulturalne, mieszkaniowe, biurowe, edukacyjne (np. przedszkole, szkoła, uczelnia wyższa) oraz religijne (Dudek-Mańkowska 2006; Twardzik 2013).

Centra handlowe pełnią też cztery istotne funkcje społeczne: pierwsza związana jest z postrzeganiem ich jako kluczowych miejsc konsumpcji współczesnego świata, druga polega na przejmowaniu przez centra handlowe pewnych wartości symbolicznych oraz kulturowych, które wcześniej odnosiły się tylko do centrum miasta. Kolejna funkcja dotyczy przypisywania galeriom handlowym znaczeń i wartości ważnych dla ich użytkowników, gdyż stają się one ulubionymi miejscami w miastach, zaspokajając jednocześnie potrzeby, które trudno byłoby zrealizować gdzie indziej (Dzieciuchowicz 2012). Czwarta funkcja centrum handlowego wiąże się z integracją społeczności miejskiej. Podstawę integracji stanowi wspólne użytkowanie przestrzeni tego typu ośrodków handlowych ${ }^{5}$. Istotne znaczenie dla sposobu funkcjonowania galerii ma jej lokalizacja. Obiekty ulokowane poza miastem pełnią zwykle funkcję obsługi handlowej, rzadziej wyposażane są w ofertę usługowo-rozrywkową. Coraz częściej inwestorzy galerii handlowych lokują je w strefie śródmiejskiej.

Galerie handlowe lokowane w dzielnicach śródmiejskich stanowią swoiste „miasto pod dachem" i oferują zestaw handlowo-usługowo-rozrywkowy w nieskazitelnych warunkach obiektu centrum handlowego (Twardzik 2014). Wielu użytkowników postrzega je jako nowe - lepsze przestrzenie publiczne, spędzając tu czas wolny wraz z rodziną czy też przyjaciółmi, korzystając z oferty usług, rozrywki i rekreacji. $Z$ kolei centra handlowe położone na peryferiach miast stanowią kompleksową ofertę handlową, począwszy od produktów żywnościowych, chemii gospodarczej, sprzętu RTV i AGD, po asortyment maszyn i urządzeń do wyposażenia domu, prac ogrodowych, meble oraz artykuły budowlane. Obiekty te zajmują zwykle większe działki, posiadają duże, bezpłatne parkingi, dogodny dojazd i przestronne, jednopoziomowe budynki. Zarówno śródmiejskie, jak i peryferyjne centra handlowe stanowią ogromną konkurencję dla pozostałych form handlu detalicznego, a ich intensywny rozwój powoduje nie tylko zmiany ilościowe w sieci handlu detalicznego, ale również zmiany o charakterze przestrzennym, społecznym i gospodarczym w miastach. Szczególne znaczenie mają

${ }^{5}$ E. Kuhne: „Współczesne centrum handlowe to już nie rynek z towarem, lecz miejsce, w którym mamy dostęp do wszelkich pomysłów na spędzenie wolnego czasu", miejscami spotkań są znajdujące się w centrach kawiarnie i restauracje, których charakter nie różni się od charakteru podobnych placówek działających poza centrum. (Wywiad przeprowadzono podczas otwarcia CH Arkadia w Warszawie). 
najnowsze inwestycje (centra IV i V generacji) łączące w swojej strukturze wielość funkcji, od handlu, usług poprzez kulturę, rozrywkę i rekreację, po funkcje biurowe, mieszkaniowe, usługi profesjonalne czy też edukacyjne (Heffner, Twardzik 2013). Klienci chętnie korzystają z ich oferty, pozytywnie oceniają sposób funkcjonowania, a także dostrzegają pozytywny wpływ na wizerunek miasta. W Katowicach funkcjonują obecnie dwie nowoczesne, śródmiejskie galerie: Silesia City Center oraz Galeria Katowicka (rys. 1).

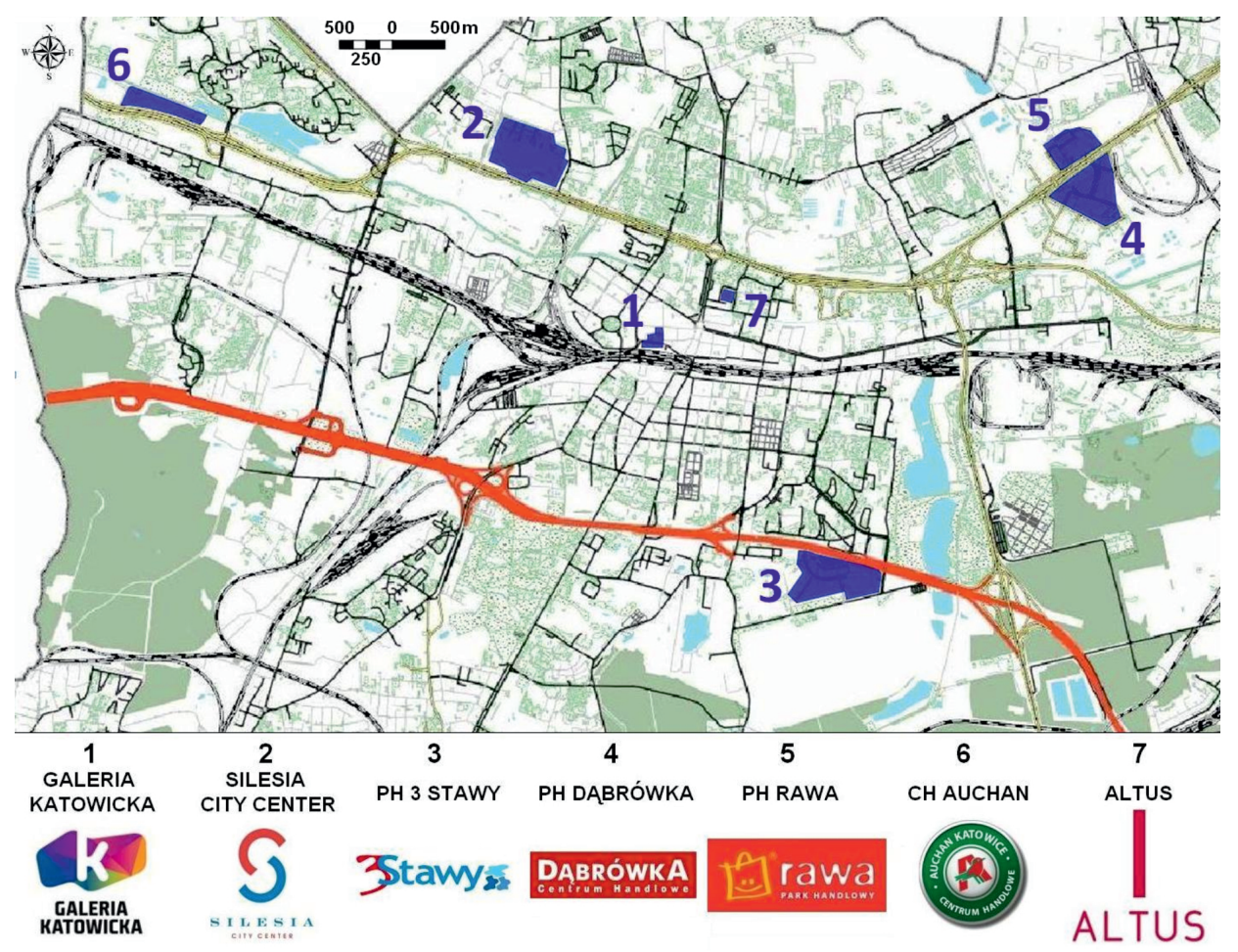

Rys. 1. Lokalizacja centrów handlowych w Katowicach

Źródło: opracowanie własne na podstawie http://mapserver.um.katowice.pl/

Silesia City Center to jeden z największych obiektów tego typu w Polsce. Galeria jest efektem udanej rewitalizacji obszaru poprzemysłowego, gdzie umiejętnie połączono tradycję i historię Górnego Śląska z nowoczesnymi rozwiązaniami architektonicznymi i otwartą, zachęcającą do odwiedzenia przestrzenią. Centrum handlowe powstało na terenie dawnej kopalni Gottwald, przed wojną znanej jako „Eminencja”. Przez blisko 100 lat miejsce to było symbolem regionu, jego rozwoju i przemysłowej tradycji. W 2000 roku inwestor podjął decyzję o zagospodarowaniu terenu, po zamkniętej w 1996 roku kopalni. Powstał projekt architektoniczny najnowocześniejszego centrum handlowego w regionie i jednego 
z najnowocześniejszych w kraju. Rozległy teren w centrum miasta zyskał zupełnie nową jakość i nową funkcję, budynki kopalni w znakomitej większości zostały zmodernizowane i stanowią część handlowo-usługową obiektu. Centrum zostało oddane do użytku 17 listopada 2005 roku, a w ciągu miesiąca odwiedziło je ponad $2 \mathrm{mln}$ osób $^{6}$.

Obecnie obiekt dysponuje $86000 \mathrm{~m}^{2}$ powierzchni handlowej, która powiększyła się po przeprowadzonej w 2011 roku rozbudowie. Bogactwo oferty, doskonała lokalizacja w pobliżu kluczowych arterii komunikacyjnych Śląska, niebanalna architektura, a przede wszystkim bezkonkurencyjna oferta handlowa (310 sklepów i punktów handlowych światowych marek) powodują, że Silesia City Center jest niekwestionowanym liderem na rynku regionalnym. Rocznie odwiedza Silesię ok. 14 mln klientów pomimo tego, że systematycznie przybywa galerii handlowych w sąsiednich miastach Aglomeracji. Rokrocznie poprawiają się wskaźniki świadczące o dynamice rozwoju tego centrum, tj. wskaźniki odwiedzin oraz obrotów. W galerii pracuje ok. 3000 osób. W obiekcie funkcjonuje ponad 300 lokali i punktów handlowo-usługowych, w tym m.in. hipermarket TESCO, Saturn, salony Empik, ZARA, C\&A, Royal Collection, Van Graf i wiele innych. W centrum można wydzielić: cześć handlową, w której znalazło się wiele prestiżowych i unikalnych w regionie marek, część rozrywkową na pierwszym piętrze centrum, której operatorami są Cinema City oraz i Jupi Park - sala zabaw dla dzieci oraz klub tańca, część gastronomiczną, tj. food court na parterze (z barami szybkiej obsługi) oraz część restauracyjną na piętrze. Ofertę uzupełniają elegancka restauracja japońska Hana Sushi, Pizza Hut, a także liczne kawiarnie. W galerii jest także strefa sportu i rekreacji, z klubem fitness sieci Gymnasion oraz siłownia sieci Pure. W Silesii City Center odbywają się wystawy czasowe, wernisaże i pokazy sztuki, mody i designu. Na terenie obiektu jest też kaplica św. Barbary. Część inwestycji stanowi ekskluzywne osiedle mieszkaniowe Dębowe Tarasy, a w przyszłości powstaną dwa budynki biurowe oraz hotel. O sile oddziaływania galerii może świadczyć promień zasięgu obsługi klientów (rys. 2), szacowany na około $60 \mathrm{~km}$.

Silesia City Center to dziś najchętniej wybierane przez klientów centrum handlowe w całym regionie, łączące postindustrialny klimat z multifunkcyjną przestrzenią handlowo-rozrywkową. Galeria stanowi miejsce zakupów i spędzania wolnego czasu dla całych rodzin, ludzi w każdym wieku, o zróżnicowanych dochodach i preferencjach. Można więc uznać, że jest to centrum handlowe nowej generacji (IV), mariaż handlu, rozrywki, kultury, funkcji mieszkaniowej, a w przyszłości biurowej, hotelowej, z bogatą ofertą najlepszych światowych marek $^{7}$.

\footnotetext{
${ }^{6}$ www.silesiacitycenter.com.pl (dostęp: 20.05.2014).

${ }^{7}$ Ibidem.
} 


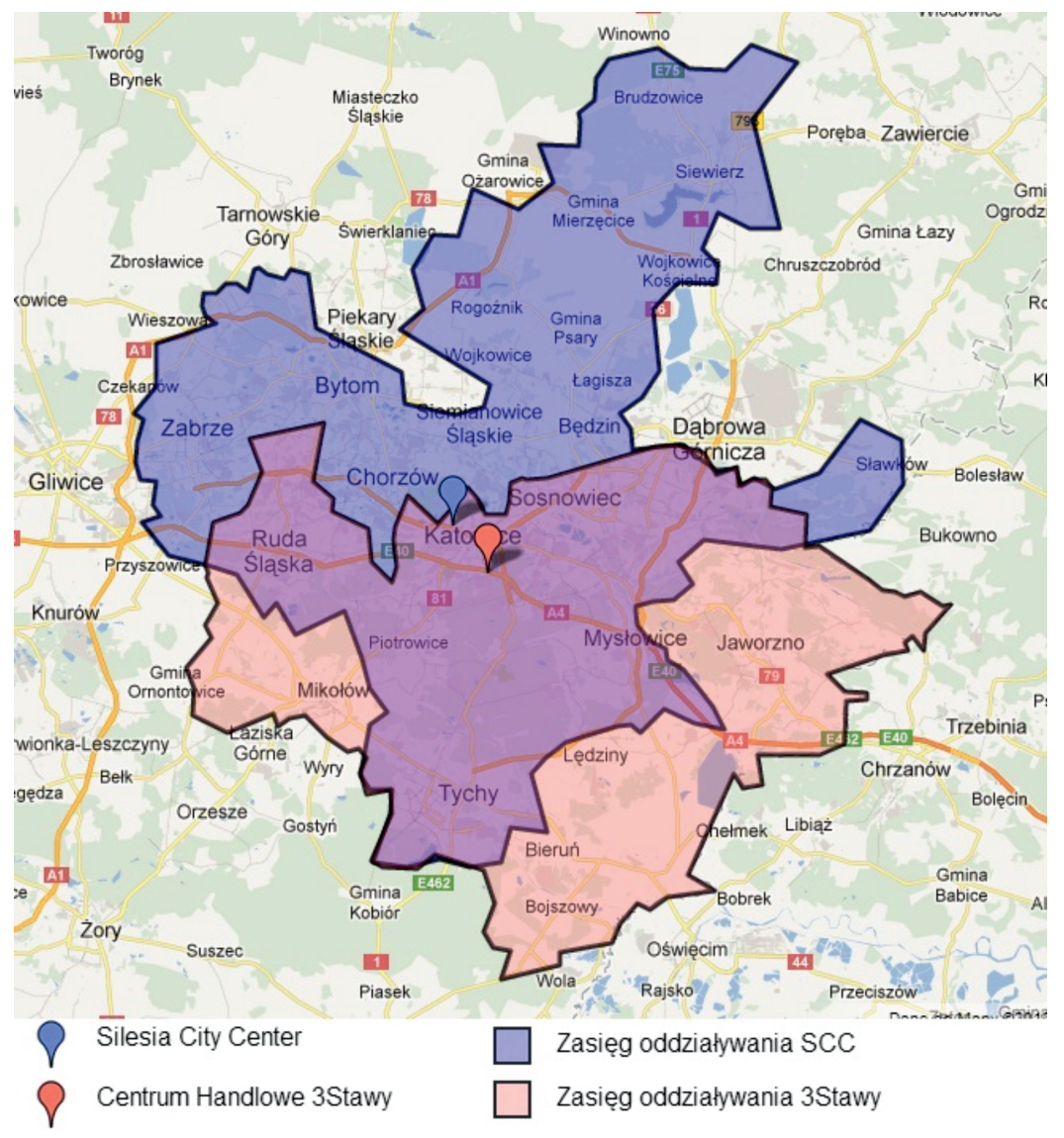

Rys. 2. Zasięg oddziaływania centrum handlowego Silesia City Center (na podstawie badania tablic rejestracyjnych 1400 klientów w dniach 21-23.06.2014) Źródło: badania bezpośrednie, czerwiec 2014

Drugim nowoczesnym obiektem tego typu w Katowicach jest śródmiejska Galeria Katowicka. Centrum powstało w 2013 roku w miejscu dworca kolejowego oraz autobusowego na placu W. Szewczyka. Galeria jest dużym $\left(53000 \mathrm{~m}^{2}\right.$ $\mathrm{GLA}^{8}$ ) centrum handlowo-usługowym IV generacji ${ }^{9}$, które oferuje 250 placówek handlowych, usługowych, gastronomicznych i rozrywkowych. Na parterze

${ }^{8}$ http://www.centrahandlowe.net/ (dostęp: 12.04.2013).

${ }^{9}$ Generacje centrów handlowych odnoszą się do etapów ich ewolucji strukturalnej, w I generacji C.H. występują placówki handlowo-usługowe, II - generacja, dodatkowo występuje oferta rozrywki, III generacja - obiekty są wyposażone w ofertę kultury i rekreacji, IV generacja - rozbudowana oferta usług profesjonalnych, kultury i rozrywki, dodatkowo funkcje mieszkaniowe, w V generacji obiekty posiadają kompleksową ofertę od mieszkań, biur, usług specjalistycznych, szkół, przychodni - po centra rozrywki i sportu. 
Galerii Katowickiej przenikają się przestrzenie handlowe, usługowe oraz dworcowe. Na nowym placu Szewczyka powstały kawiarnie i restauracje z letnimi ogrodami. Dzięki temu zabiegowi plac stał się przestrzenią publiczną przyjazną mieszkańcom i turystom, tętniącą życiem, która wraz z elementami małej architektury służy jako miejsce wypoczynku i rozrywki. W podziemnej części znajduje się parking na 1200 miejsc postojowych. Pierwsza i druga kondygnacja zarezerwowana jest dla mody - znajdują się tu lokale odzieżowe i obuwnicze światowych producentów. Najbardziej reprezentacyjną część obiektu stanowi Aleja Mody na poziomie drugim - miejscu dawnego tarasu „wychodzącego" na plac Szewczyka. Przeszklona konstrukcja łącząca oba obiekty (centrum handlowe oraz dworzec kolejowy) uwalnia naturalne światło, eksponując rozłożyste surowe żelbetonowe konstrukcje. Są one podstawą konstrukcji nowej hali dworca, wyznaczając również kształt witryn sklepowych o niespotykanej wysokości $9 \mathrm{~m}^{10}$. Projekt przewiduje także wolnostojący budynek biurowy, zlokalizowany w pobliżu dworca kolejowego od strony ul. Młyńskiej. Obiekt powstanie w niedalekiej przyszłości i będzie posiadał siedem kondygnacji. Większość powierzchni będzie przeznaczona na funkcje biurowe, natomiast poziom parteru inwestor przeznaczy pod działalność handlowo-usługową. Zrealizowany projekt inwestycyjny przebudowy i zagospodarowania terenu dworca kolejowego to najdroższa inwestycja w zakresie rozwoju i rewitalizacji przeprowadzona w Katowicach w ostatnim czasie. Galeria Katowicka staje się symbolem śródmieścia - a w przyszłości może stanowić jedną z wizytówek miasta. Mieszkańcy od początku jej powstania chętnie korzystają $\mathrm{z}$ oferty tego miejsca robiąc zakupy, korzystając $\mathrm{z}$ usług oraz spędzając wolny czas.

Obie galerie oferują bardzo zróżnicowany asortyment handlowo-usługowy, są postrzegane jako nie tylko miejsca zakupów - ale przede wszystkim miejsca spędzania wolnego czasu dla całych rodzin, ludzi w każdym wieku, przyjazne, przyjemne i czyste. Liczne badania ${ }^{11}$ przeprowadzane w ostatnich latach potwierdzają te opinie, a rosnące zainteresowanie nowoczesną wielofunkcyjną przestrzenią galerii coraz bardziej wpływa na funkcjonowanie ulic śródmiejskich, szczególnie w zakresie zmieniających się warunków ekonomicznych przedsiębiorców prowadzących działalność handlowo-usługową. Centra handlowe są dużymi kompleksami, które mają wpływ na tereny sąsiednie. Ich oddziaływanie na rozwój podmiotów gospodarczych w bezpośrednim otoczeniu jest zróżnicowany i w dużej mierze zależy od położenia danego centrum w strukturze miasta oraz od istniejących form zagospodarowania terenu (Rochmińska 2013).

${ }^{10}$ Dossier prasowy, Przebudowa dworca kolejowego w Katowicach. Budowa Galerii Katowickiej, Wydawnictwo PKP i NEINVER, 2011, s. 11-12.

${ }^{11}$ Badania w zakresie funkcjonowania oraz atrakcyjności centrów handlowych przeprowadzono w 2013 roku w Łodzi. Wskazano również na pięć typów oddziaływania galerii na otoczenie. Szerzej na temat: A. Rochmińska (2013). 


\section{4. Śródmiejskie ulice handlowe w Katowicach}

Struktura funkcjonalno-przestrzenna Katowic podlega dynamicznym i wielokierunkowym zmianom. Związane są one zarówno z występowaniem zjawisk typowych dla aglomeracji wielkomiejskich, jak też procesem restrukturyzacji gospodarczej, specyficznym dla Aglomeracji Górnośląskiej. Zanikanie pierwotnych funkcji miastotwórczych - przemysłu ciężkiego, głównie branży górniczej i hutniczej przyczynia się do uwalniania rozległych terenów, zazwyczaj o bardzo dobrej lokalizacji, likwidacji znacznej części rozbudowanej infrastruktury kolejowej oraz przekształcania terenów produkcyjno-składowych w usługowe, bądź usługowo-składowe, a w niektórych przypadkach mieszkaniowe ${ }^{12}$. Inne, często występujące zmiany w zagospodarowaniu przestrzennym Katowic, są typowe dla większości dużych polskich miast. W Katowicach na terenach poprzemysłowych powstają nowoczesne obiekty handlowe, tj. centra handlowe, super i hipermarkety, niewielkie developerskie osiedla o zabudowie mieszanej, budynki biurowe oraz hotele. Zmiany funkcjonalno-przestrzenne następują bardzo dynamicznie, a krajobraz miasta nie przypomina już przemysłowego centrum aglomeracji. W obecnym układzie urbanistycznym Katowic widoczne są ślady historii miasta oraz ewolucji jego powstawania, czego wyrazem jest fragmentaryczna kompozycja przestrzenna. W obecnych granicach administracyjnych, poza właściwym miastem Katowice ukształtowanym od drugiej połowy XIX wieku do lat 20. XX wieku, znajduje się kilkanaście dzielnic i osiedli będących przed przyłączeniem do Katowic odrębnymi jednostkami administracyjnymi, a także zespołów zabudowy powstałych po poszerzeniu granic miasta.

Centrum Katowic jest fragmentem środkowej części Śródmieścia, zawartym pomiędzy terenami kolejowymi na południu, ul. Chorzowską i aleją W. Roździeńskiego na północy oraz wschodniej i zachodniej granicy definiowanej na dwa sposoby. Wschodnią granicę centrum stanowią ulice Francuska i Bankowa lub Graniczna i J. Dudy-Gracza, natomiast zachodnią granicę centrum wyznaczają ul. Sokolska, plac Wolności, ul. J. Matejki lub ulice W.F. Grundmanna i Sądowa (rys. 3).

W zależności od przyjętej metodologii, powierzchnia centrum wynosi od 73 do 150 ha, a liczba mieszkańców od 7,8 tys. do ponad 12 tys. osób ${ }^{13}$. Bez względu na przebieg wschodniej oraz zachodniej granicy, centrum zajmuje obszar Katowic ukształtowany w jego dwóch najważniejszych fazach rozwojowych: XIX-wiecznej, kiedy powstała oś plac Wolności - ul. 3 Maja - Rynek - ul. Warszawska, a także w latach 60. i 70. ubiegłego wieku, gdy miała miejsce przebudowa osi Rynek - al. Korfantego - rondo gen. J. Ziętka. Ze Śródmieściem najsilniej powiązane przestrzennie są jednostki urbanistyczne tworzące od 1924 roku

${ }^{12}$ Studium uwarunkowań i kierunków zagospodarowania..., s. 23.

${ }^{13}$ Ibidem, s. 24. 
tzw. Wielkie Katowice, czyli dzielnice Załęże, Załęska Hałda, Dąb, Koszutka, Bogucice, Zawodzie, Brynów i Ligota. Niejednorodny stopień powiązania ze Śródmieściem charakteryzuje wschodnie dzielnice miasta, będące do 1960 roku samodzielnymi jednostkami administracyjnymi. Wyraźna jest również odrębność południowej części miasta, najpóźniej przyłączonej do Katowic. W poszczególnych dzielnicach, wcześniej niezależnych gminach, wyodrębnić można szereg mniejszych jednostek urbanistycznych - osiedli, osad, kolonii, które cechuje zróżnicowana geneza, historia i stan zachowania (Abramski 2000; Szaraniec 2010).

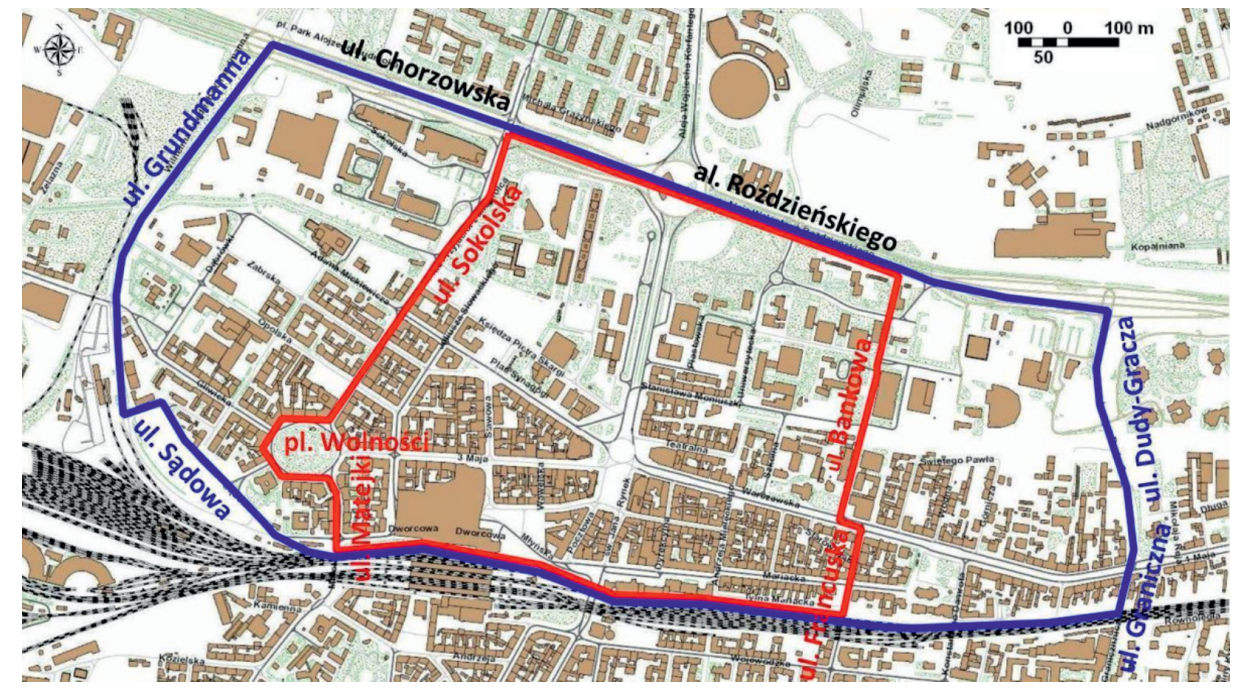

Rys. 3. Przestrzenny zasięg centrum Katowic

Źródło: opracowanie własne na podstawie http://mapserver.um.katowice.pl/

Funkcjami porządkującymi oraz hierarchizującymi strukturę funkcjonalno-przestrzenną Katowic są funkcje metropolitalne. Zbiór funkcji metropolitalnych miasta stanowią: nauka i szkolnictwo wyższe, kliniki, specjalistyczne usługi medyczne, kultura wysoka, sztuka, wydawnictwa, administracja publiczna i związków wyznaniowych, media komunikacji społecznej, sprzedaż hurtowa i wielkopowierzchniowa, w tym wielofunkcyjne galerie handlowe, transport międzynarodowy, instytucje finansowe i ubezpieczeniowe, doradztwo prawne, ekonomiczne oraz technologiczne (Raport o stanie miasta Katowice 2005).

Wszystkie wymienione rodzaje funkcji metropolitalnych skupione są głównie w obszarze zespołu dzielnic śródmiejskich. Współistnieją one z tradycyjnymi funkcjami egzogenicznymi, zarówno z funkcją przemysłową, jak też bardziej powszechnie występującą funkcją usługową. Tego typu przemieszanie funkcji ma negatywny wpływ na wizerunek zespołu dzielnic śródmiejskich. Funkcje o zasięgu ponadlokalnym są także skupione w zespołach dzielnic zachodnich 
i wschodnich. W zespole dzielnic zachodnich, występują funkcje z zakresu nauki i szkolnictwa wyższego oraz specjalistycznych usług medycznych. Natomiast zespół dzielnic wschodnich wyposażony jest w funkcje związane z nauką oraz sprzedażą hurtową i wielkopowierzchniową. Na obszarze zespołów dzielnic północnych i południowych zlokalizowane są tradycyjne funkcje zewnętrzne, w szczególności związane z wytwórczością i handlem oraz uzupełniające, zwłaszcza mieszkaniowe i rekreacyjne.

W części śródmiejskiej Katowic funkcjonuje kilka ulic handlowych, z czego za najbardziej reprezentacyjną uznaje się ul. 3 Maja. Handlowo-usługowy charakter posiadają też ulice: Warszawska, A. Mickiewicza, Stawowa, Dyrekcyjna, Mariacka, W. Korfantego, Młyńska, Pocztowa, św. Jana, Staromiejska, Teatralna i ul. ks. P. Skargi. Tradycyjnie istotnym miejscem handlowym miasta jest rynek. Katowicki Rynek jest najstarszym i głównym placem miasta. Dobiegają do niego, bądź też od niego wychodzą poza ulicami 3 Maja i Warszawską, aleja W. Korfantego oraz A. Mickiewicza, Młyńska, Pocztowa, św. Jana i Staromiejska. W latach 60. i 70. ubiegłego wieku tuż przy Rynku w miejscu zniszczonych historycznych kamienic powstały nowoczesne na tamte czasy obiekty handlowe i usługowe: Dom Prasy Śląskiej, Dom Handlowy „Zenit” i Dom Handlowy „Skarbek” (Grzegorek 2012). Od 2002 roku z kamienicy przyległej do Rynku wygrywany jest katowicki hejnał. W 2012 roku rozpoczęła się przebudowa katowickiego Rynku, która ma zostać zrealizowana do końca 2015 roku $^{14}$.

Ulica 3 Maja uznawana jest za najbardziej reprezentacyjną i najdroższą w mieście. Według badań przeprowadzonych w 2009, 2010 i 2013 roku przez agencję Cushman \& Wakefield jest ona piątą najdroższą ulicą w Polsce. Jednym ze wskaźników badań była średnia cena $1 \mathrm{~m}^{2}$ powierzchni użytkowej, która dla ul. 3 Maja wynosiła wówczas około 700 Euro (Grzegorek 2012) ${ }^{15}$. W 2014 roku ul. 3 Maja znalazła się na siódmym miejscu w Polsce, a stawki wynajmu szacowano na 636 Euro za $1 \mathrm{~m}^{2}$ powierzchni użytkowej, co świadczy o spadku cen w stosunku do roku 2013 o 5,4\% (Twardzik 2014). Jest ona zamknięta dla regularnego ruchu kołowego - pełni funkcję deptaka. Obecnie działa przy niej wiele punktów handlowo-usługowych, instytucji i przedsiębiorstw, a od września 2013 roku również centrum handlowe - w południowej pierzei ulicy otwarto połączoną $\mathrm{z}$ dworcem kolejowym Galerię Katowicką. Ulica Warszawska pełni głównie funkcję komunikacyjną, będąc jedną z ważniejszych dróg wyjazdowych z centrum miasta w kierunku wschodnim. Wyposażona jest głównie w placówki handlowe oferujące odzież, obuwie oraz asortyment spożywczy. Większość śródmiejskich ulic miasta posiada też bardzo zróżnicowaną ofertę usług finansowych, począwszy od placówek bankowych, poprzez kasy pożyczkowe, chwilówki, ubezpieczalnie i placówki doradztwa finansowego. W ofercie ulic śródmiejskich są również

\footnotetext{
${ }^{14}$ www.przemiana.katowice.eu (dostęp: 16.05.2014).

${ }^{15}$ G. Grzegorek (2012, s. 37).
} 
placówki usługowe, głównie gastronomiczne, naprawcze oraz edukacyjne (tj. szkoły językowe, placówki oferujące kursy i szkolenia). Specyficzny charakter posiada ul. Mariacka, która została zrewitalizowana w 2008 roku i przekształcona w deptak o długości 360 m (Grzegorek 2012). Jest ona współcześnie miejscem wielu wydarzeń kulturalnych, m.in. rozmaitych imprez plenerowych, koncertów i happeningów. Przy ul. Mariackiej mieści się kilkanaście klubów muzycznych, restauracji, barów oraz innych lokali gastronomicznych. Istotne znaczenie komunikacyjno-transportowe ma aleja W. Korfantego, przy której ulokowało się wiele sklepów i lokali usługowych.

Funkcjonalne centrum miasta pozostało w swojej pierwotnej, historycznej lokalizacji, zarówno ze względu na zbyt słabą koncentrację funkcji centrotwórczych w zabudowie wokół Rynku i na odcinku alei W. Korfantego prowadzącym do ronda, jak też z powodu małej podatności na zmiany funkcjonalne - brakuje przede wszystkim lokali gastronomicznych i rozrywkowych, które ożywiały by przestrzeń publiczną.

W przestrzeni śródmiejskiej Katowic występują też nowoczesne obiekty handlowe, m.in. handlowo-usługowo-biurowy Altus wraz z hotelem Cubus, będący najwyższym budynkiem w mieście, super- i hipermarkety, centra handlowe i spożywcze, sieci dyskontowe. Wielkopowierzchniowe obiekty handlowe zlokalizowane są $\mathrm{w}$ centrum miasta lub w bezpośrednim sąsiedztwie dzielnicy śródmiejskiej, przy głównych trasach komunikacyjnych Katowic. Przejęły one część funkcji handlowo-usługowych, które w tradycyjnym systemie sieci handlowej pełni centrum miasta, a także ośrodki dzielnicowe oraz osiedlowe. Dwa obiekty mieszczą się w ścisłym centrum miasta - Galeria Katowicka i budynek Altus, natomiast w bliskim sąsiedztwie Śródmieścia znajdują się Silesia City Center, parki handlowe 3 Stawy, Dąbrówka i Rawa, a także C.H. Auchan. Konkurencja nowoczesnego handlu istotnie oddziałuje na kondycję ekonomiczną przedsiębiorstw funkcjonujących w ulicach śródmiejskich miasta, pozbawiając je systematycznie części dochodów ze sprzedaży oraz świadczonych usług. Widoczna jest duża rotacja najemców powierzchni w Śródmieściu oraz przybywająca systematycznie ilość placówek bankowych oraz kas pożyczkowych. Pojawiają się coraz częściej puste, niewynajęte lokale w najbardziej reprezentacyjnych miejscach Śródmieścia, co może być konsekwencją rosnącej konkurencji ze strony nowoczesnych galerii handlowych. Klienci wybierają galerie handlowe nie tylko na miejsca zakupów, ale też spędzania czasu wolnego, korzystając z ich oferty rekreacyjnej i kulturalnej. W marcu 2014 roku przeprowadzono badania bezpośrednie ${ }^{16}$, które

${ }^{16}$ Badania bezpośrednie przeprowadzono w grupie 400 respondentów (na ulicy śródmiejskiej 3 Maja oraz w Galerii Katowickiej), dobranych celowo, kryterium - klient galerii handlowych oraz placówek handlowych w ulicach śródmiejskich. W grupie badanych znalazło się 61,9\% kobiet. Przyczyną takiego rozkładu płci może być większa liczba kobiet robiących zakupy. Najliczniejszą grupą wiekową były osoby młode z przedziału 
miały na celu rozpoznanie opinii mieszkańców oraz pozostałych użytkowników miasta na temat funkcjonowania tradycyjnych ulic handlowych miasta oraz galerii handlowych, a także zakresu ich oddziaływania na ulice śródmiejskie Katowic.

\section{Oddziaływanie galerii handlowych na śródmiejskie ulice handlowe Katowic}

Galeria Katowicka powstała w 2013 roku i z powodzeniem działa w centrum miasta, czego efektem jest systematycznie rosnąca liczba klientów ${ }^{17}$. Z kolei główna ulica śródmiejska (3 Maja) od kilku lat boryka się z problemem wynajmu lokali, a od momentu powstania galerii problem się nasilił, co powoduje degradację znaczenia ulicy. Podobna sytuacja występuje w strukturze najmu innych ulic centrum Katowic, szczególnie tych położonych w bliskiej odległości od nowych formatów handlu - takich jak super i hipermarkety oraz sklepy dyskontowe. Przeprowadzone badania wykazały, że do głównych ulic handlowych miasta respondenci zaliczają ulice: 3 Maja, Stawową, Staromiejską i Mickiewicza, zdecydowanie najczęściej deklarując ul. 3 Maja jako destynację zakupową. Blisko 5\% badanych uważa, że w mieście nie ma ulicy handlowej, a kolejne 5\% wskazywało inne ulice, jak np. Mariacką oraz aleję Korfantego. Struktura branżowa działalnosci przy ulicach handlowych Katowic wyróżnia się dużym nagromadzeniem lokali usługowych oraz sklepów z odzieżą, obuwiem i bielizną. Usługi to $20 \%$ udziału w rynku przy ulicach handlowych i $15 \%$ w centrach handlowych. Działalności usługowe prowadzone w lokalach przy ulicach śródmiejskich to głównie banki i kasy pożyczkowe, drobne usługi naprawcze oraz serwisowe, a także związane

od 18 do 29 roku życia (44,1\%), osoby w średnim wieku (30-39 lat) stanowiły 24,6\% respondentów. Pozostałe grupy wiekowe liczyły łącznie 30,5\% ogółu ankietowanych; z przedziału pomiędzy 40-49 rokiem życia 13,6\% osób, natomiast w wieku 50-64 lat stanowili 16,9\% ogółu badanych. Najmniejszą ilościowo grupą wiekową wśród ankietowanych była grupa osób w wieku poprodukcyjnym (0,8\%). Respondenci legitymujący się średnim wykształceniem stanowili ponad połowę (56,8\%) badanych, 35,6\% - to osoby z wykształceniem wyższym, a 7,6\% - zawodowym. Pod względem aktywności zawodowej w grupie badanych znaleźli się pracownicy biurowi (29,7\%), fizyczni (26,3\%) oraz uczniowie i studenci $(22,0 \%)$. Pozostali to osoby prowadzące własną działalność gospodarczą $(5,1 \%)$, nauczyciele $(1,7 \%)$ oraz lekarze $(0,8 \%)$. Gospodarstwo domowe prawie $1 / 3(32,2 \%)$ ankietowanych liczyło 4 osoby, dwu lub trzyosobowe stanowiły połowę respondentów - odpowiednio 24,6\% i 25,4\%. Najmniej liczną grupą osób w przeprowadzonym badaniu były jednoosobowe gospodarstwa domowe $(6,8 \%)$. Badani oceniali status ekonomiczny jako dobry (59,3\%) lub dostateczny $(22,9 \%)$, niemal co piąty respondent wskazał na sytuację bardzo dobrą 17,8\%. Przeważającą grupą osób, które wzięły udział w badaniu były osoby mieszkające poza miastem Katowice (55\%), najczęściej pochodzący z miast położonych w Aglomeracji Górnośląskiej. Badania przeprowadzone zostały przez grupę ankieterów UE w Katowicach, autor opracowania koordynował ich przebieg.

${ }^{17}$ Badania przeprowadzone na zlecenie Galerii Katowickiej w marcu oraz wrześniu 2014 roku, wzrost liczby odwiedzających galerię w tym czasie o 4,2\%. 
z obsługą telefonii komórkowej. Placówki usługowe ulokowane w centrach handlowych to głównie serwisy pielęgnacyjne i obsługujące rynek sieci komórkowych i usług turystycznych. W centrum miasta wiele lokali pozostaje pustych, wynajęte - dosyć szybko rotują ${ }^{18}$. Szacuje się, że udział lokali pustych do wynajęcia w ich całkowitej liczbie przy ulicach handlowych miasta wynosi ok. 9-10\% ${ }^{19}$. Klienci częściej kupują w galeriach i lepiej oceniają warunki zakupowe niż na ulicach śródmiejskich pod względem wyboru towarów, organizacji przestrzeni, czystości, bezpieczeństwa oraz atmosfery (rys. 4). Można więc uznać, że galerie handlowe są bezkonkurencyjne względem ulic śródmiejskich dla klientów, spełniając ich potrzeby i oczekiwania.

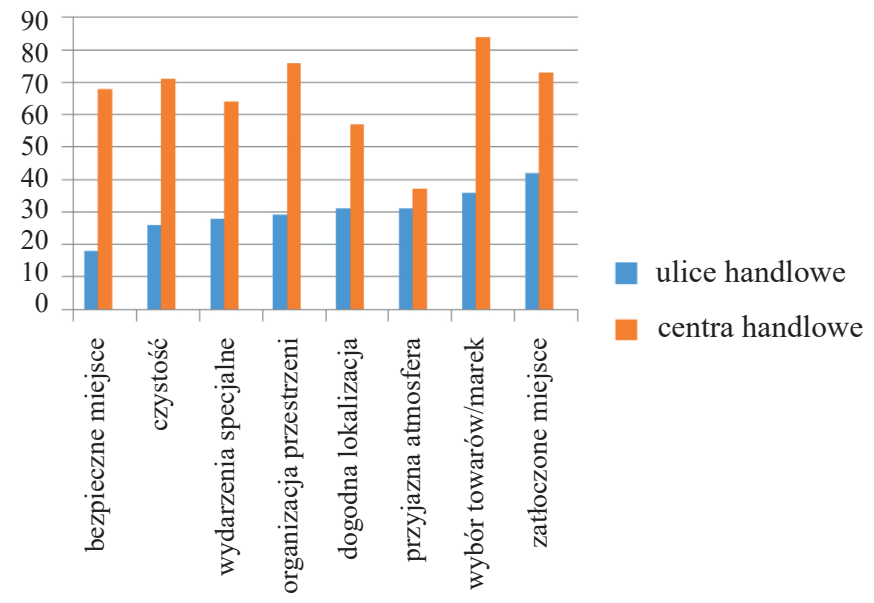

Rys. 4. Ulice handlowe i centra handlowe w opinii mieszkańców Katowic Źródło: opracowanie własne

Wśród osób deklarujących zakupy w galeriach handlowych najwięcej jest osób młodych do 39 roku życia, aktywnych zawodowo, o dobrej i bardzo dobrej sytuacji ekonomicznej, częściej z Katowic niż z innych miast. Respondenci korzystający z oferty ulic śródmiejskich to ludzie zamieszkujący centrum miasta, w wieku 50-64 lata, którzy mają ugruntowane tradycyjne rozumienie handlu ${ }^{20}$. Są wśród nich też osoby do 29 roku życia, którzy korzystają z oferty gastronomicznej śródmieścia lub kulturalno-rozrywkowej (np. ul. Mariacka). Największe wydatki przy ulicach handlowych konsumenci deklarują na gastronomię oraz artykuły

${ }^{18}$ Według badań prowadzonych przez UM Katowice oraz zespół Katedry Gospodarki Przestrzennej UE w Katowicach, rotacja powstających działalności odbywa się średnio co 16 miesięcy.

${ }^{19}$ Wyniki badań bezpośrednich.

${ }^{20} \mathrm{~W}$ badaniach zapytano respondentów o to, jak rozumieją pojęcie handel. 
spożywcze (73\%), na produkty typu moda, obuwie i bielizna (71\%). Kolejne miejsce na liście zakupowej klientów ulic stanowią produkty i usługi typu zdrowie i uroda (64\%), a następnie multimedia (51\%) i artykuły specjalistyczne (40\%) - rys. 5. Z kolei w galeriach handlowych najczęściej (91\%) kupują artykuły spożywcze, odzież, obuwie i kosmetyki. Klientami galerii są według badań młode kobiety (29-40 lat), aktywne zawodowo i deklarujące dobrą sytuację ekonomiczną. Młodzi ludzie korzystający z oferty galerii to często „oglądacze” wystaw, spędzający wolny czas, a nawet wagarowicze. Osoby po 64 roku życia przychodzą do galerii w poszukiwaniu okazji cenowych i promocji, na spacer oraz obejrzeć wystawy sklepowe.

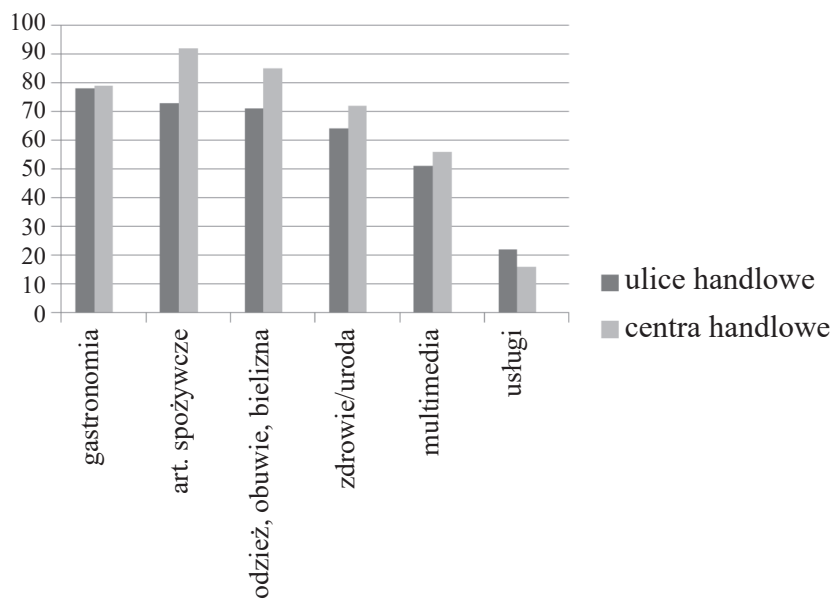

Rys. 5. Wydatki konsumentów w podziale na wybrane kategorie

Źródło: opracowanie własne

W przypadku galerii handlowych zakupom sprzyja atmosfera, ciepło, czystość i uniezależnienie od warunków pogodowych. Ma to związek z czasem realizacji zakupów. Czas jednorazowej wizyty przy ulicy handlowej, dla większości (71\%) respondentów to mniej niż 1 godz. Niemal co trzeci ankietowany przebywa tam jednorazowo powyżej godziny. Można przypuszczać, że są to szybkie, celowe zakupy. Znacznie więcej czasu zabiera im wizyta w centrum handlowym $-80 \%$ respondentów spędza tam jednorazowo powyżej 1 godz., z czego niemal połowa określa ten czas między 1 a 2 godzinami (rys. 6).

Badani wskazali powody, dla których robią zakupy przy ulicach handlowych i w galeriach handlowych. W przypadku ulic są to zakupy okazjonalne, przypadkowe - często przy okazji innych spraw, w drodze na dworzec kolejowy/autobusowy lub „po drodze” (rys. 7). 


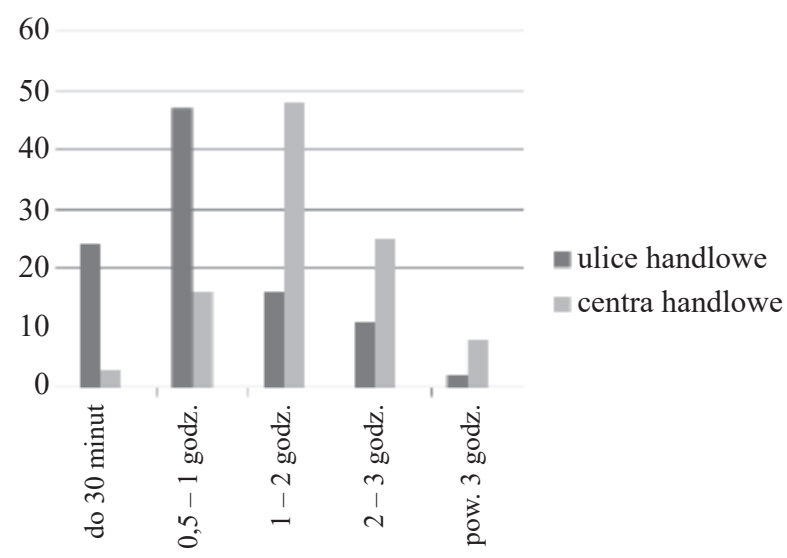

Rys. 6. Długość wizyty jednorazowej w galerii handlowej oraz w ulicach handlowych Źródło: opracowanie własne

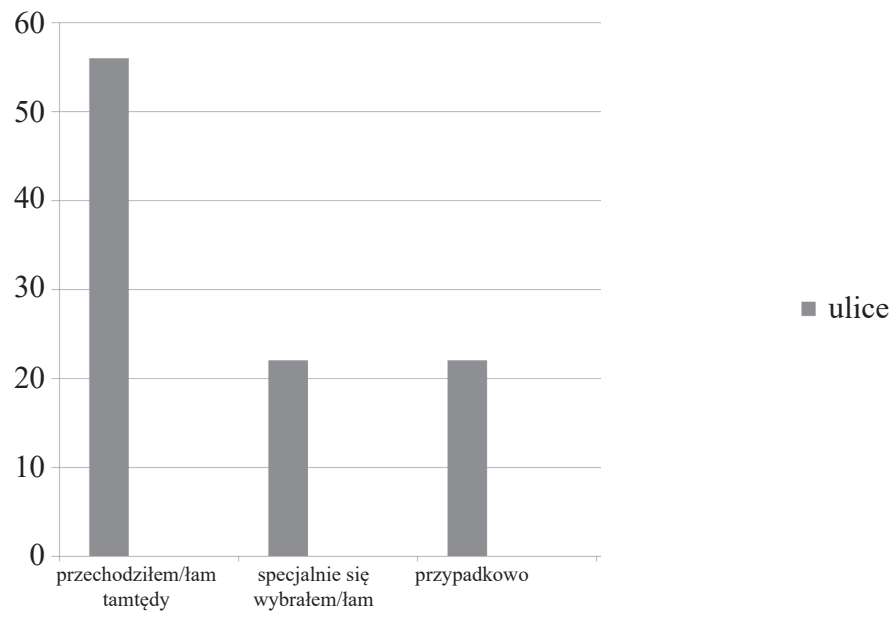

Rys. 7. Zakupy przy ulicach handlowych $(\mathrm{N}=342)$

Źródło: opracowanie własne

Ulica handlowa jest konkretnym celem zakupowym dla 21\% badanych, zazwyczaj są to osoby przyzwyczajone do danej placówki handlowej, konkretnego asortymentu, obsługi sklepowej lub po prostu mają blisko domu. Częściej badani deklarują zakupy w galerii, która jest dla nich miejscem kompleksowo wyposażonym, modnym i wygodnym (rys. 8).

Klienci galerii handlowych doceniają przede wszystkim ich kompleksową ofertę i wygodę, ponadto lubią je i dlatego chętnie spędzają tam czas. Takie deklaracje wyrażają zarówno kobiety, jak i mężczyźni, osoby w różnym wieku, wskazujący na dobrą i bardzo dobrą sytuację materialną. Osoby aktywne zawodowo, 
oprócz zakupów częściej korzystają z usług galerii oraz oferty rekreacyjnej. Wygodę zakupów pod jednym dachem oraz modne miejsce podkreślają kobiety, natomiast mężczyźni uznają je za kompleksowe i wygodne komunikacyjnie (bezpłatny parking, dogodny dojazd).

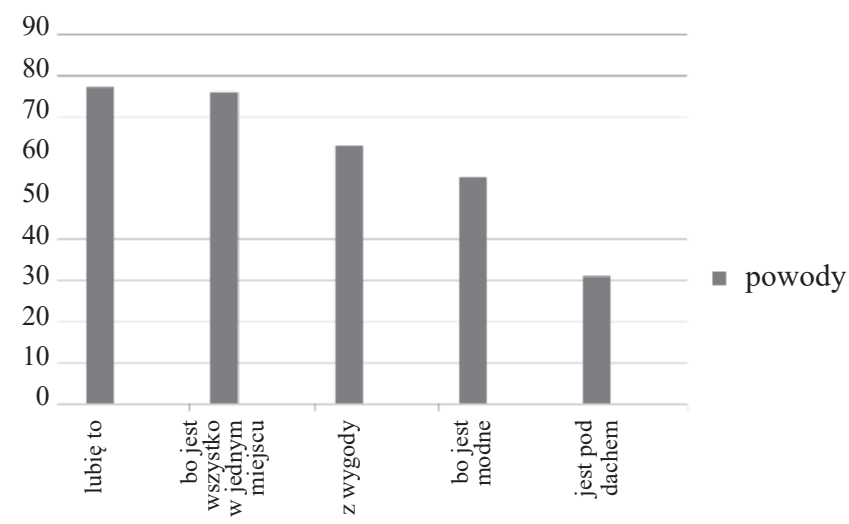

Rys. 8. Zakupy w galeriach handlowych $(\mathrm{N}=396)$

Źródło: opracowanie własne

Ważnym czynnikiem dla badanych jest możliwość łatwego dojazdu do galerii oraz bezpłatnego (3 godz.) zaparkowania samochodu ( $88 \%$ badanych). Z kolei jednym $z$ istotnych mankamentów zakupów przy ulicy handlowej są trudności z zaparkowaniem samochodu, ograniczona możliwość dojazdu, czy też inne trudności komunikacyjne, takie jak korki, roboty drogowe $\mathrm{e}^{21}$ oraz utrudnienia w ruchu śródmiejskim z uwagi na dużą liczbę sygnalizacji świetlnych (78\%). Sytuacja, w której znakomita większość klientów korzysta z komunikacji indywidualnej, warunki dostępnego i bezpłatnego parkowania często determinują wybór miejsca zakupów. Rozpatrując trudności parkingowe dużych miast w Polsce, w tym również Katowic nie można zagwarantować, że sytuacja ulic śródmiejskich poprawi się w najbliższej przyszłości. Wygodę zakupów pod jednym dachem oraz modne miejsce podkreślają kobiety, natomiast mężczyźni uznają je za kompleksowe i wygodne komunikacyjnie (bezpłatny parking, dogodny dojazd).

\section{Wnioski}

Reasumując należy stwierdzić, że nowe wielofunkcyjne galerie handlowe coraz częściej wygrywają rywalizację ze śródmiejskimi ulicami handlowymi dzięki kompleksowej ofercie, lepszej obsłudze komunikacyjnej, w tym głównie

${ }^{21} \mathrm{~W}$ mieście od połowy 2012 roku trwają remonty śródmiejskich dróg oraz torowisk tramwajowych, są liczne objazdy i utrudnienia w ruchu. 
rozwiązując problem parkowania, uniezależnieniu od warunków pogodowych, wysokiemu poziomowi technologicznemu w zakresie organizacji handlu i usług, nowoczesnemu wystrojowi obiektu, organizacji usług dla klienta oraz ochronie budynku. Wraz z rozwojem centrów handlowych w województwie śląskim obserwuje się systematyczny wzrost udziału powierzchni obiektów rekreacyjno-rozrywkowych $\mathrm{w}$ ich strukturze ${ }^{22}$ oraz spadek udziału powierzchni placówek handlowych w ogólnej powierzchni najmu. Wielofunkcyjne obiekty realizowane na wzór i podobieństwo dzielnic śródmiejskich imitują „miasta pod dachem” i stwarzają wygodne warunki realizacji zakupów i spędzania czasu wolnego. Ulice handlowe nie znajdują sposobu na efektywną konkurencję i przegrywają walkę o klienta. Usługi finansowe lokowane w śródmieściu nie rozwiązują problemu, a w przyszłości mogą go jedynie nasilać, biorąc pod uwagę rozwój bankowości elektronicznej, co w konsekwencji prowadzi do zamykania tradycyjnych placówek bankowych. Coraz mniej atrakcyjna oferta śródmiejska, niedostatek miejsc parkingowych, coraz więcej pustostanów i wysokie stawki czynszu powodują degradację handlowo-usługową dzielnicy. Nowoczesne galerie, będące przedsięwzięciem komercyjnym, dysponujące określoną strategią i doświadczeniem ekspansywnie przejmują klientów, oferując im coraz więcej towarów i usług, coraz taniej i bardziej wygodnie.

W tej sytuacji należy zastanowić się nad dalszym kierunkiem rozwoju miasta, w szczególności sieci handlu detalicznego oraz warunkami lokalizacji wielkopowierzchniowych galerii handlowych. Badania nad oddziaływaniem galerii na strukturę funkcjonalno-przestrzenną miast powinny przyczynić się do zmiany akcentów w planowaniu rozwoju gospodarczego i przestrzennego miast, ze szczególnym uwzględnieniem struktury sieci handlowo-usługowej.

\section{LITERATURA}

Abramski A., 2000, Ulice Katowic, Wydawnictwo Graf-Mar, Zawiercie.

Centra Handlowe - rynek, konsument, kariera - Raport Coliers International, 2014, (aut. M. Knap).

Domański T., 2001, Strategie marketingowe dużych sieci handlowych, PWN, Warszawa/ Łódź.

Dudek-Mańkowska S., 2006, Funkcje wybranych centrów handlowych w Warszawie, [w:] Jażdżewska I. (red.), Nowe przestrzenie w mieście, ich organizacja i funkcje, Wydawnictwo UŁ, Łódź.

Dzieciuchowicz J., 2012, Wielkie centrum handlowe w przestrzeni miejskiej i podmiejskiej, Wydawnictwo UŁ, Łódź.

Euromonitor Internatinal, GUS, 22.09.2014.

${ }^{22} \mathrm{~W}$ strukturze najmu galerii handlowych w Katowicach w latach 2010-2014 nastąpił wzrost powierzchni obiektów rekreacyjno-rozrywkowych o 6\%. Można tu wskazać: klub tańca, teatr: scena w galerii, klub malucha itp. W tym okresie nastąpił spadek udziału powierzchni najmu placówek handlowych w katowickich galeriach o ponad 4\%. 
Grzegorek G, 2012, Ulice i place Katowic, Wydawnictwo Prasa i Książka, Katowice.

Heffner K., Twardzik M., 2013, The impact of shopping malls on the outer metropolitan zones (the example of the Silesian Voivodeship), „Studia Regionalia KPZK PAN”, 37, Warszawa.

Lukić A., Jakovčić M., 2004, Location and Functions of Hypermarkets and Shopping Centres in Zagreb, „Dela”, 22.

Matysiak N., 2009, Współczesne centra handlowe w Polsce, „Handel Wewnętrzny”, 6.

Maryas J., Kunc J., Tonev P., Szczyrba Z., 2014, Shopping and Services related Travel in the Hinterland of Brno: Changes from the Socialist Period to the Present, „Moravian Geographical Reports", 22(3).

Pilarczyk B., Sławińska M., Mruk H., 2001, Strategie marketingowe przedsiębiorstw handlowych, Wydawnictwo PWE, Warszawa.

Raport o stanie miasta Katowice, 2005, Katowice.

Rochmińska A., 2013, Atrakcyjność tódzkich centrów handlowych oraz zachowania nabywcze i przestrzenne ich klientów, Wydawnictwo UŁ, Łódź.

Strużycki M., 2000, Koncentracja w handlu a wspótpraca producentów $i$ dystrybutorów, Wydawnictwo Instytutu Rynku Wewnętrznego i Konsumpcji, Warszawa.

Szaraniec L., 2010, Osady i osiedla Katowic, Wydawnictwo Naukowe Śląśk, Katowice.

Studium uwarunkowań i kierunków zagospodarowania przestrzennego miasta Katowice $\mathrm{z}$ dnia 25 kwietnia 2012 roku.

Twardzik M., 2013, Development of shopping malls in Poland, [in:] Heffner K., Twardzik M., (eds.), The impact of shopping malls on the outer metropolitan zones (the example of the Silesian Voivodeship), „Studia Regionalia KPZK PAN”, 37, Warsaw, s. 85-102.

Twardzik M., 2014, Nowoczesny handel w przestrzeni miast Aglomeracji Górnoślaskiej, Wydawnictwo UE Wrocław, Wrocław.

\title{
Źródla internetowe
}

Www.silesiacitycenter.com.pl (dostęp: 23.06.2014).

www.centrahandlowe.net (dostęp: 12.04.2013).

www.przemiana.katowice.eu (dostęp: 16.05.2014).

\section{THE IMPACT OF SHOPPING CENTERS ON THE DOWNTOWN SHOPPING STREETS IN KATOWICE}

\begin{abstract}
Shopping centers have become an integral part of the structure of modern cities in Poland. In Katowice, there are two malls in the downtown district and interact in many ways the functioning of Katowice. Considering their place in the structure of the chain of retail and service center, we can said, that both contribute to the economic revival of the downtown area, evidence may numerous food service places, recreation, service and retail and commercial drainage function of the inner-city streets.
\end{abstract}

Key words: galleries/malls, modern trade, city, downtown district.

Dr inż. Małgorzata Twardzik Katedra Gospodarki Przestrzennej Wydział Ekonomii, Uniwersytet Ekonomiczny w Katowicach 